\title{
What Happened to Your College Town: The Changing Relationship of Higher Education and College Towns, 1940-2000
}

\author{
Kate Rousmaniere* (iD) \\ Department of Educational Leadership, Miami University, Oxford, Ohio, USA \\ *Corresponding author. Email: rousmak@miamioh.edu
}

\begin{abstract}
This essay examines the history of what is commonly called the town-gown relationship in American college towns in the six decades after the Second World War. A time of considerable expansion of higher education enrollment and function, the period also marks an increasing detachment of higher education institutions from their local communities. Once closely tied by university offices that advised the bulk of their students in off-campus housing, those bonds between town and gown began to come apart in the 1970s, due primarily to legal and economic factors that restricted higher education institutions' outreach. Given the importance of off-campus life to college students, over half of whom have historically lived off campus, the essay argues for increased research on college towns in the history of higher education.
\end{abstract}

Keywords: town gown; college town; off-campus housing; college student housing; in loco parentis

A typical workday for Carl Opp, director of Off-Campus Housing at the University of Florida in 1961, included checking on a broken bike rack at an off-campus house; mediating an argument between college student tenants (which one of you caused the fire extinguisher problem? which one of you threw water from the balcony?); addressing the complaints of a student tenant whose fan was stolen by local football players and another whose two quarts of rum were stolen from his house; advising a prospective tenant who was married, had children, and needed an apartment on the bus line; investigating why a number of maids were quitting their jobs cleaning off-campus apartments; addressing a rumor that maids were stealing tenants' food; calling a plumber to address sewage backups, a flooded basement, and a clogged sink; talking with landlords about a flea infestation allegedly caused by a student renter who violated the lease by bringing in cats; and counseling student tenants about ways to respond to noisy neighbors, roommate problems, unrefunded down payments, and landlords who turned the electricity off in the middle of the semester. After spending a day dealing with such issues, Opp wrote: "These days make me feel like a doctor trying to deal w/ an epidemic."

\footnotetext{
${ }^{1} 1961$ work diary, box 16, Carl Braden Opp Papers, 1930-80, MS Collection 13, George A. Smathers Library, University of Florida, Gainesville (hereafter cited as Opp Papers).

(c) History of Education Society 2021. This is an Open Access article, distributed under the terms of the Creative Commons Attribution licence (http://creativecommons.org/licenses/by/4.0/), which permits unrestricted re-use, distribution, and reproduction in any medium, provided the original work is properly cited.
} 
Between 1955 and 1978 Opp led the University of Florida's Off-Campus Housing Office of the Division of Housing, which functioned as a listing, inspection, advising, and referral agency for all rental housing requested by university students, faculty, and staff - a number that by 1970 averaged an annual 20,000 clients. For over thirty years, the staff of at most seven housing inspectors, counselors, and clerks compiled and cross-referenced records of available housing and prospective renters, helped undergraduate students negotiate what was often their first lease, coordinated a university process of confirming approved student housing that aligned with local health and safety codes, and developed informational handbooks for students planning to live off campus. In addition, the office addressed various local, state, and national developments, including identifying emergency shelters during hurricane season and applying antidiscriminatory requirements to approved student housing as a result of the federal Fair Housing Act of $1968 .^{2}$ By the mid-1970s, this work accelerated when a record-breaking cohort of baby boomers began their freshman year of college, leading to a housing shortage in which, as the student newspaper caustically reported, students were doubled up in dormitory rooms like "sardines." 3 According to Opp, fall 1974 was the worst year ever, when his office struggled to house hundreds of students in "inadequate and dilapidated housing located from west hell to north Georgia."

In spite of the crisis of the 1970s, by the fall semester of 1977, the Off-Campus Housing staff was cut in half and the section's budget drastically reduced. When Opp retired the following spring, the dean of students cut the office staff again and announced "the end of an era," which was "a logical time to evaluate the services we should be offering to our students as relate to off-campus housing." According to the dean, a number of factors led to these changes, including the 1971 passage of the Twenty-Sixth Amendment, which lowered the age of majority from 21 to 18 , and, in the previous decade, a series of court decisions that limited the legal ability of higher education institutions to monitor students when off campus. Simultaneously, decreasing state and federal funding led to cutbacks in university services. Even though inspections of and formal advising for off-campus housing would end, the dean promised that the university would continue its practice of maintaining contact with the local community. ${ }^{5}$ At least one town resident disagreed, writing the dean the following year:

Many homeowners in single family neighborhoods close by campus are angry that these areas have been taken over by students. We feel [that] the University of Florida is wrong to increase its enrollment when it cannot accommodate more students. We also believe more pressure should be applied by Student Affairs, President Marston, and others in a position to do so to put controls on students living off campus. ${ }^{6}$

\footnotetext{
2“The University of Florida Off-Campus Housing Program, Feb. 6, 1969," Opp Papers.

3"Sardines," editorial, Independent Florida Alligator (University of Florida), March 4, 1975, 6.

4"Eruption," editorial, Independent Florida Alligator (University of Florida), July 3, 1975, 8.

${ }^{5}$ Off-Campus Housing Office, memo, May 26, 1978, Opp Papers.

${ }^{6}$ Mildred G. Auth to Arthur Sandeen, vice president for student affairs, Feb. 13, 1979, subseries 49d, Vice President for Student Affairs Administrative Policy Records 1970-1987, George A. Smathers Library, University of Florida, Gainesville.
} 
Opp's career at the University of Florida exemplifies the history of what is commonly called the town-gown relationship in university towns in the six decades after the Second World War. A time of considerable expansion of higher education enrollment and function, the period also marks an increasing detachment of higher education institutions from their local communities. Once closely tied by university offices that advised the bulk of their students in off-campus housing, those bonds between town and gown began to come apart in the 1970s, due primarily to legal and economic factors that restricted higher education institutions' outreach.

Most people see the nature of college towns as the result of culture: through a nostalgic haze of college memories, there is a sense that students create and shape college towns and that they contribute to a college town's character through volunteerism and participation in the local economy. ${ }^{7}$ All this may be true at the local and individual level. At a more systematic level, however, college towns, like other communities, have been structured by both university and government interventions. ${ }^{8}$ Specifically referring to the role of higher education in urban development, Margaret O'Mara argues that university investment in cities creates "consciously planned communities" that are "shaped by the relationship between the state and civil society in late twentieth-century America."

This essay explores the structural dynamics that led to a significant change in town-gown relations in the late twentieth century, and particularly in the 1970s, when universities largely turned their backs on off-campus life, leaving college towns to pick up much of that work. This trajectory was not inevitable; through the mid-1960s, many universities, led by staff like Opp, were intensely engaged in their students' residential life in the local community, serving as a lynchpin for towngown relations. By the 1970s, however, legal and fiscal challenges led universities to withdraw from those commitments. ${ }^{10}$

\section{Before the Dorm: Three Hundred Years of Town-Gown Relations}

American higher education from the colonial period through the early twentieth century was essentially a local enterprise that owed its origins and early support to the

\footnotetext{
${ }^{7}$ Blake Gumprecht, The American College Town (Amherst: University of Massachusetts Press, 2010). For all its solid research, Gumprecht's book comes from the perspective of emphasizing student life and culture as the core of college towns.

${ }^{8}$ Richard Rothstein, The Color of Law: A Forgotten History of How Our Government Segregated America (New York: Liveright Publishing, 2017); and Margaret Pugh O’Mara, Cities of Knowledge: Cold War Science and the Search for the Next Silicon Valley (Princeton, NJ: Princeton University Press, 2015).

${ }^{9} \mathrm{O}$ 'Mara, Cities of Knowledge, 1.

${ }^{10} \mathrm{My}$ focus is on college towns and public institutions of higher education in the Midwest and South, where I had access to rich archives, and a selection of other institutions around the country, including some private colleges with primary and secondary resources, including legal cases and municipal records. The common denominator for all the research here is the location of the institution in a "college town," defined loosely as a town or small city where colleges are a dominant presence in the community and where college students comprise at least 20 percent of a town's population. Gumprecht provides additional distinguishing characteristics of a college town (pp. 4-16), although the International Town \& Gown Association, which provides networks and support for "institutions of higher education and the communities in which they reside" makes no such distinction. "Misson and Vision," International Town \& Gown Association, https://www.itga.org/about/mission. The major goal of the study is to identify common themes, rather than present specific case studies.
} 
town in which it was located. Many nineteenth-century American towns sought colleges to help "boost" a joint public culture and economy. ${ }^{11}$ Well through the nineteenth century, virtually all college students lived off campus, since most institutions did not have the housing capacity or economic base to develop residence halls. Nor was there an expectation to do so, as higher education was literally only about academic study, removed from the potential distractions of family life. ${ }^{12}$ In the years before significant state or federal funding, colleges survived on tuition alone and were able to develop capital building projects only with individual donations. Through the late nineteenth century, institutions of higher education thus relied heavily on the local community to provide places for students to sleep after class. From students' perspective, local housing was one of the few maneuverable financial pieces of a college education. ${ }^{13}$

By the early twentieth century, college and university leaders saw housing as a mechanism for student recruitment and retention, and they began to develop strategies for providing and managing student housing. The development of student clubs, fraternities, and sororities both on and off campus also furthered this goal, as did, at some elite private institutions, the creation of a more systematic plan of student residential colleges on campus. ${ }^{14}$ Some universities purchased or subsidized local community housing options, such as housing co-ops that charged reduced rent in exchange for student labor. Such operations usually functioned at a financial loss, introducing the first conflicts between university budget offices that were concerned with fiscal matters and early student affairs offices that were concerned with student matters. $^{15}$

Yet well through the Second World War, most higher education students continued to rely on community housing. For example, when William Tate arrived at the University of Georgia as a first-year student in September 1920, he walked from the train station into town and secured housing in a family home, where he shared a room and bed with another male student. In exchange for rent, the two students

\footnotetext{
${ }^{11}$ James W. Thomas, "Campus as Home: An Examination of the Impact of Student Housing at the University of Kentucky in the Progressive Era" (PhD diss., University of Kentucky, 2017); Kolan Morelock, Taking the Town: Collegiate and Community Culture in the Bluegrass, 1880-1917 (Lexington: University Press of Kentucky, 2008); and David B. Potts, "American Colleges in the Nineteenth Century: From Localism to Denominationalism," History of Education Quarterly 11, no. 4 (Winter 1971), 363-80.

${ }^{12}$ William H. Cowley, "The History of Student Residential Housing," School and Society 40 (Dec. 1934), 705-12; Arnold H. Diamond, "The College Housing Program: Its History and Operations," Educational Record 38, no. 3 (July 1957), 204-19; and Charles F. Frederickson, "A Brief History of Collegiate Housing," in Student Housing and Residential Life: A Handbook for Professionals Committed to Student Development Goals, ed. Roger B Winston Jr. (San Francisco: Jossey-Bass, 1993), 167-83.

${ }^{13}$ Jana Nidiffer and Jeffrey P. Bouman, "The University of the Poor': The University of Michigan's Transition from Admitting Impoverished Students to Studying Poverty, 1870-1910," American Educational Research Journal 41, no. 1 (Jan. 2004), 35-67.

${ }^{14}$ Guillermo De Los Reyes and Paul Rich, "Housing Students: Fraternities and Residential Colleges," Annals of the American Academy of Political and Social Science 585, no. 1 (2003), 118-23.

${ }^{15}$ F. McElhenie, Making Do and Getting Through: KU Co-ops, Halls, and Houses, 1919-1966 (Lawrence, KS: Historic Mount Oread Fund, 2006); and W. Cobb, comptroller, to President E. A. Gilmore, May 25, 1935, box 4, Cooperative Dormitories folder, University Housing Records, University of Iowa Special Collections, University of Iowa, Iowa City.
} 
shared a bath and meals with the landlord and his family. Tate lived in a fraternity his sophomore year but found the house too noisy, and he spent his junior and senior years renting a room from Miss Anne Brumby. ${ }^{16}$

Miss Brumby's case was not unusual; indeed, independent housing rentals in the form of boarding and rooming houses constituted the backbone of a local housing economy in college towns through the mid-twentieth century and offered one of the few ways local families and independent women could generate income. In Gainesville, Florida, in the 1930s, half of all rooming house operators were financially dependent upon University of Florida's student rent. Of those, two-thirds were widows and one-quarter were married women whose husbands were "unable to provide a family living." 17 In many college towns, the local private economy came to rely on the student rental market as a constant income generator in a community that lacked a local industry.

But the absence of health and social regulations for such housing increasingly bothered higher education administrators, particularly with the early twentieth-century expansion of the legal and professional doctrine of in loco parentis, literally meaning "in the place of a parent." In the 1913 Gott v. Berea College case, the Kentucky Court of Appeals ruled that Berea College could prohibit students from patronizing local restaurants because the college stood in loco parentis, regarding the physical and moral welfare of its students. ${ }^{18}$ In the years after the First World War, the concept of in loco parentis expanded from being primarily about student disciplinary control to the responsibility of higher education to literally "be a better parent" by developing advisory and socialization programs through which the institution looked after the whole student, "both body and mind."19 As the student personnel (later student affairs) profession expanded in this period, the university's obligation extended far outside of the classroom to living arrangements. ${ }^{20}$ Early deans of students looked with alarm at the absence of regulations around the independent housing market that accommodated a majority of their students. Boarding houses, where students rented a single room, were of particular concern because no overarching regulatory umbrella assured students safe and healthy living. ${ }^{21}$ Boarding houses also challenged middle-class values that higher education

\footnotetext{
${ }^{16}$ William Tate, "Reminiscences" (1971), folder 15, box 84, Papers of Dean William Tate, Dean of Men, Hargrett Library, University of Georgia, Athens (hereafter cited as Papers of Dean William Tate).

${ }^{17}$ J. A. Connor, "Survey of Housing Conditions at the University of Florida" (master's thesis, University of Florida, June 1931).

${ }^{18}$ Gott v. Berea College, 156 Ky. 376 (1913); Gavin Henning, "Is In Consortio Cum Parentibus the New In Loco Parentis?" NASPA Journal 44, no. 3 (Sept. 2007), 540; and Kerry B. Melear, "From In Loco Parentis to Consumerism: A Legal Analysis of the Contractual Relationship Between Institution and Student," NASPA Journal 40, no. 4 (Oct. 2003), 124-48.

${ }^{19}$ Christopher P. Loss, "Institutionalizing in Loco Parentis after Gott v. Berea College (1913)," Teachers College Record 116, no. 12 (2014); and Christopher P. Loss, Between Citizens and the State: The Politics of American Higher Education in the 20th Century (Princeton, NJ: Princeton University Press, 2014).

${ }^{20}$ Michael S. Hevel, "Toward a History of Student Affairs: A Synthesis of Research, 1996-2015," Journal of College Student Development 57, no. 77 (Oct. 2016), 844-62; and Christine A. Ogren and Marc A. VanOverbeke, eds., Rethinking Campus Life: New Perspectives on the History of College Students in the United States (New York: Palgrave Macmillan, 2018).

${ }^{21}$ In 1903, twenty-nine Cornell students died in a typhoid epidemic in a boarding house in Ithaca, New York. Heather Munro Prescott, "Sending Their Sons into Danger: Cornell University and the Ithaca Typhoid Epidemic of 1903," New York History 78, no. 3 (July 1997), 273-308; Connor, "Survey
} 
sought to instill in students because they allowed unsupervised commingling of people from diverse backgrounds and existed solely as a financial transaction. ${ }^{22}$

When Tate became dean of men at the University of Georgia in 1946, he may well have reflected on his own eclectic housing experience as a student as he worked to establish a more comprehensive system of supervising and regulating off-campus housing for students. In this work he joined other new deans of men and women who developed processes for matching individual students with private housing arrangements and negotiating with local homeowners about rental policies and social supervision.

White women students at newly coeducational institutions received special advice in their housing: the new administrative position of dean of women was created largely to supervise and regulate women students' housing since, through the midcentury at many coeducational institutions, barely a third of all women students were allocated dormitory space on campus. Many deans of women personally identified and approved off-campus housing for women students, often literally walking the streets to find acceptable landladies who would house women tenants and provide an appropriate family-like structure, social regulation, and proper nutrition, discipline, and academic support. ${ }^{23}$

Students of color at newly desegregated universities also received attention for housing, but for significantly different reasons. Most predominantly White universities prohibited students of color from living on campus by law, policy, or custom until well into the 1960s. The first Black students who battled for admission then suffered the indignities of being denied a room on campus or assigned to their own wing of a dormitory to prevent their interaction with White students. ${ }^{24}$ Many universities in both the North and South effectively steered Black students to racially segregated neighborhoods off campus because White college-area landlords often refused to rent to Black students. ${ }^{25}$ These off-campus housing arrangements provided income for local Black families and social support for students of color who were excluded from most campus activities, although the accommodations were typically far from campus. $^{26}$ By prohibiting Black students from campus residence halls, university leaders could abide by desegregation court rulings that required integration in the

of Housing Conditions," 80; and Donald Roger Mallett, "A Study of Effects of an Organized Personnel Program" (Master's thesis, University of Iowa, 1934).

${ }^{22}$ Carla Yanni, Living on Campus: An Architectural History of the American Dormitory (Minneapolis: University of Minnesota Press, 2019), 21, 53, 97, 123.

${ }^{23}$ Carolyn Terry Bashaw, "Stalwart Women": A Historical Analysis of Deans of Women in the South (New York: Teachers College Press, 1999); Jana Nidiffer, Pioneering Deans of Women: More Than Wise and Pious Matrons (New York: Teachers College Press, 2000); and Kelly Sartorius, Deans of Women and the Feminist Movement: Emily Taylor's Activism (New York: Springer, 2014).

${ }^{24}$ Kate Rousmaniere, "'Desegregated but Not Integrated': Race and the Politics of Student Housing in American Higher Education History," in Change and Continuity in American Colleges and Universities, ed. Nathan M. Sorber (Milton Park, UK: Routledge, 2020).

${ }^{25}$ Richard M. Breaux, "'Maintaining a Home for Girls': The Iowa Federation of Colored Women's Clubs at the University of Iowa, 1919-1950," Journal of African American History 87, no. 2 (Spring 2002), 236-55; Elizabeth L. Ihle, Black Women in Higher Education: An Anthology of Essays, Studies, and Documents (Milton Park, UK: Taylor \& Francis, 1992); and Glenda Alice Rabby, The Pain and the Promise: The Struggle for Civil Rights in Tallahassee, Florida (Athens: University of Georgia Press, 1999).

${ }^{26}$ Lena M. Hill and Michael D. Hill, eds., Invisible Hawkeyes: African Americans at the University of Iowa During the Long Civil Rights Era (Iowa City: University of Iowa Press, 2016); and Charles F. Robinson II 
classroom but not elsewhere on campus, as well as take pressure off local White landlords to integrate. Restrictions on housing facing Black college students remained so severe through the 1960s that, in spite of minimal attempts by some institutions to adopt antidiscrimination housing policies, many civil rights activists felt that access to both on- and off-campus residential facilities remained the final barrier to equity in higher education. ${ }^{27}$ Other newly admitted cohorts of students-including women, international students, and students with disabilities-found the lack of acceptable housing to be a major barrier to their academic success, and through the $1960 \mathrm{~s}$ they organized some of the earliest campus political movements to assure adequate and accessible housing. ${ }^{28}$

By mid-century, the availability and accessibility of housing, both on and off campus, represented a critical factor in students' experiences of higher education. Historically, the local housing economy played a central role in supplementing university housing in a kind of mutual-aid agreement in which they worked largely independently of each other but reinforced each other. What the university could not provide, or did not want to provide, the community did, working in some reciprocal, but inconsistent, coordination. When housing was unavailable on campus, or it was inaccessible or unacceptable, students looked to the community, and institutions of higher education increasingly played a role in helping students become a part of that community.

\section{Higher Education Enters the Housing Business}

The first systemic economic investment of higher education in the business of housing began in the late 1940s with the rapid enrollment of returning World War II veterans on the GI Bill. Veteran enrollment was not only large-some universities' enrollment doubled or tripled in size within a few years-it also introduced the first significant number of married students to campuses, a population that continued to grow over the subsequent decades as universities expanded their graduate student enrollment. $^{29}$

To help house the new veteran students, universities partnered with the federal government in providing prefabricated housing, Quonset huts, and trailers in distinct

and Lonnie R. Williams, Remembrances in Black: Personal Perspectives of the African American Experience at the University of Arkansas, 1940s-2000s (Fayetteville: University of Arkansas Press, 2015).

${ }^{27}$ Guy B. Johnson, "Racial Integration in Public Higher Education in the South," Journal of Negro Education 23, no. 3 (Summer 1954), 317-29; United States Commission on Civil Rights, Equal Protection of the Laws in Public Higher Education (Washington, DC: Government Printing Office, 1960); and Buell G. Gallagher, ed., NAACP College and the Black Student: NAACP Tract for the Times (Baltimore, MD.): National Association for the Advancement of Colored People, 1971), 17.

${ }^{28}$ Christy Oslund, Disability Services and Disability Studies in Higher Education: History, Contexts, and Social Impacts (New York: Springer, 2014); and Scot Danforth, "Becoming the Rolling Quads: Disability Politics at the University of California, Berkeley, in the 1960s," History of Education Quarterly 58, no. 4 (Nov. 2018), 506-36.

${ }^{29}$ Victor A. Christopherson, "College Marriage in Public and Private Institutions of Higher Education, 1943-1958," Family Life Coordinator 8, no. 3 (March 1960), 49-52; and William H. Marshall and Marcia P. King, "Undergraduate Student Marriage: A Compilation of Research Findings," Journal of Marriage and the Family 28, no. 3 (Aug. 1966), 350-59. 
housing communities colloquially called "Vet Villages." Coordinating with local city zoning boards, universities purchased public land that was often disconnected from campus and paid for site-development costs as well as additional accessories that older students demanded, including parking lots, laundry rooms, storage units, gardens, and children's playgrounds. Managing those sites was unusually complex, as the director of housing at the University of Georgia experienced through the late 1940s. His job involved overseeing more than three hundred housing units and troubleshooting family rental issues, which included monitoring the presence of pet dogs, cats, chickens, and rabbits (all prohibited by city ordinance) and addressing problems with sewer, water, electricity, heating, gardens, screens, laundry facilities, and, in July 1948, a polio scare. ${ }^{30}$

As the veteran enrollment bulge subsided, it was replaced by an increasing number of older married students, many of whom arrived from overseas or across the country for newly instituted graduate programs. By 1960, 24 percent of full-time American students were married, and those numbers only increased with the introduction of draft deferrals for married men and men with dependent children. ${ }^{31}$ Now experienced with handling off-campus student housing from the veterans' experience, higher education leaders came to see constructing and managing adequate housing for all students, both on and off campus, as a major responsibility of the institution. Through the 1950s, many universities replaced temporary army barracks with new off-campus housing complexes for married students that the university subsidized and supervised. ${ }^{32}$

In these years, most university student housing for married and unmarried students, on and off campus, was funded in part by federal and state loans. In particular, two funding bills were designed to expand higher education and make it more accessible: the 1950 College Housing Loan Program offered educational institutions low-cost loans to provide student and faculty housing, and the Higher Education Facilities Act of 1963 authorized funding for "academic and related facilities" for public and other nonprofit institutions of higher education. ${ }^{33}$ Many of these housing

\footnotetext{
30“To All Trailer Occupants,” Nov. 10, 1948, folder 1, box 77, 1945-49, Papers of Dean William Tate.

${ }^{31}$ Dongbin Kim and John L. Rury, "The Changing Profile of College Access: The Truman Commission and Enrollment Patterns in the Postwar Era," History of Education Quarterly 47, no. 3 (Aug. 2007), 309.

${ }^{32}$ The University of Kentucky was the first university to provide designated affordable off-campus housing for married students in the mid-1950s when the university constructed two apartment complexes with five hundred units. Many universities also developed an administrative planning office for married student housing that addressed common residential issues, including the demands of organized tenants. "Married Students Housing," folder 4, box 34, RG 15/F2, Records of the Rutgers University Dean of Student Affairs (Earl W. Clifford, Jr.), 1952-1973, Rutgers University Archives (New Brunswick, N.J.) E. G. Williamson, "Postwar College Housing," Journal of Higher Education 15, no. 9 (Dec. 1944), 465-69; "Housing Married Students," folder 4, box 167, Administrative and General Files, 1963-2001, General Reference Subject Files, Special Collections Research Center, University of Kentucky, Lexington; and "Married Student Housing at the State University of Iowa with particular reference to the Hawkeye Apartment Project," April 28, 1958, Married Student Housing folder 1956-65, box 4, RG 26.04.01, University Housing Records (formerly Residence Services Records), University of Iowa Special Collections, Iowa City.

${ }^{33}$ Frederickson, “A Brief History of Collegiate Housing," 172; Isreal Ratkind, The Federal Government's College Housing Loan Program: A Critique and an Alternative (Washington, DC: American Council on Education, 1966); John J. Agria, College Housing: A Critique of the Federal College Housing Loan Program, vol. 1 (Washington, DC: American Enterprise Institute for Public Policy Research, 1972); and
} 
loans depended on repayment from other residence hall operations-a requirement that would prove challenging to universities in later years.

As their off-campus holdings increased, many institutions also formalized the advising responsibilities of the dean of students with the creation of an off-campus housing office, like that which Opp directed at the University of Florida beginning in 1955. Hired by the university, housing office staff engaged in deep communication and negotiation with city and state government officials and local housing developers and landlords. To further their efficiency, some off-campus housing directors participated in joint city-university zoning and housing commissions as well as university student affairs committees as they juggled the double demands of town and gown. Often trained in the new profession of student personnel services, some offices also took on the responsibility of socializing off-campus students by sponsoring dances, intramural athletic events, and networking opportunities.

Central to the work of these offices was designating and maintaining "approved housing lists," which indicated to students that the listed property had passed health and safety inspections and university provisions that in some cases included prohibiting landlords from discriminating on the basis of race, religion, or national origin. Ostensibly, students were only permitted to rent a unit that the housing office had approved, although in reality, given their limited staff, university housing offices could inspect only a minority of available properties, nor could they assure ongoing compliance. For example, at the University of Kentucky in 1964, the housing director estimated that only about one-third of available privately owned apartments had been inspected and rated, and the office handled housing for only half of all male students living off campus. At the University of Iowa at this time less than 10 percent of the houses that students lived in had been inspected. ${ }^{34}$ Because inspection was only part of the responsibility of these offices, which also provided rental listings and student counseling, many were overwhelmed by attending to both student needs and city and university requirements. So notorious was the pressure on understaffed housing offices that, in 1959, the newly organized Association of College and University Housing Officers (ACUHO) described university attention to off-campus housing as "the neglected stepchild of university life."35

However inadequate, such offices comprised some of the strongest town-gown partnerships in the history of American higher education, effectively serving as the only formal link for students between the university and their off-campus life, affording the college town community with some regulatory oversight of the growing number of student residences, and providing counseling to students about where, and sometimes how, to live on their own. When Opp died in 1981, three years after retiring, he was still remembered by University of Florida students for his three decades of helping "thousands of harassed university students in their darkest

Fred J. Brieve and Ray V. Mayfield Jr., "Emerging Student Housing Patterns in the Small College," Journal of Higher Education 41, no. 3 (March 1970), 225-27.

${ }^{34}$ John Alexander, "Town Housing Office at UK Plays Part in Many Students' Lives," Lexington (KY) Leader, April 29, 1964; and "Committee Announces New Policies on Off-Campus Housing Discrimination," Daily Iowan (University of Iowa), May 28, 1963, 1.

${ }^{35}$ Research Committee, "1959 Report on Noninstitution-Owned Housing” (Columbus, OH: Association of College and University Housing Officers, 1959). 
hour" as they searched for places to live. He "strived mightily to put decent roofs over their heads when no decent roofs were on the horizon." Given the absence of other supports for students' off-campus life, Opp was the "underdog's champion." 36

\section{Withdrawal}

While higher education enrollments grew steadily in the 1940s and 1950s, they accelerated considerably from the late 1950s through the early 1970s with the enrollment of the baby boom generation. For example, while The Ohio State University enrollment increased in the twelve years between 1938 and 1950 from 13,000 to 20,000, its enrollment doubled from 25,000 to 50,000 in the mere ten years between 1960 and $1970 .^{37}$ In addition to the sheer numerical increase, the baby boomer college students who entered higher education in this period were older, more racially and ethnically diverse, more likely to study and work part time, more likely to be female, and, particularly in the late 1960s and early 1970s, more inclined toward independent and countercultural lifestyles.

To accommodate the increasing number of students, many universities built dormitories at a feverish pace through the 1950s and 1960s, funded in part by federal grants and loans. The sheer size of the on-campus housing boom of the period was aptly illustrated by one observer, who noted that during the 1960s American higher education built enough new dormitories "to house the populations of Cleveland and Boston." 38 The geography of individual campuses became revolutionized: between 1950 and 1970, The Ohio University enrollment more than quadrupled, from 4,000 to 19,000 , and the university built eighteen new dormitories. ${ }^{39}$ Cornell University built seven residence halls for 1,200 students in the 1950 s alone. ${ }^{40}$ But even with this massive construction, universities could not keep up with the skyrocketing enrollment, and many campuses suffered a severe housing shortage, doubling up students in dormitory rooms and lounges. Campus dormitories also increasingly dissatisfied students who objected to the impersonal design- "a sterile cell along a stark corridor," as one Ohio University student described it-and social regulations through the famed parietal system that limited visiting hours between men and women and the age at which students were permitted to live off campus. ${ }^{41}$

It was not only outdated and crowded dormitories that led students to flock off campus. A lot of students were already off campus as the proportion of students who lived with their parents and commuted to campus increased from a third of all college students to almost half between 1960 and 1980. Whether commuting to

\footnotetext{
${ }^{36}$ Carl Braden Opp, obituary, Gainesville (FL) Sun, Nov. 3, 1981, 15.

${ }^{37}$ Jennifer S. Evans-Cowley, "The Effect of Neighborhood-Based Code Enforcement in University Communities: The Case of The Ohio State University," Planning, Practice \& Research 21, no. 1 (Feb. 2006), 109-20.

${ }^{38}$ Elizabeth A. Greenleaf, “Residence Halls 1970's," NASPA Journal 7, no. 2 (1969), 65.

${ }^{39}$ Doug McCabe, ed., Vernon R. Alden: An Oral History (Athens: Ohio University Libraries, 1999), 244.

${ }^{40}$ Gumprecht, American College Town, 93.

${ }^{41}$ Lonnie Fouty, "Campus Architecture: Building Behind the Times," April 10, 1967, box 1C, series 1, Campus Plan, Presidential Papers of Vernon R. Alden, 1962-1969, Robert E. and Jean R. Mahn Center for Archives and Special Collections, Ohio University, Athens; and Betty Hollow, Ohio University: The Spirit of a Singular Place: 1804-2004 (Athens: Ohio University, 2003), 192.
} 
four-year or the newly burgeoning two-year colleges, commuting became the largest category of beginning college students during the 1970 s. $^{42}$ Simultaneously, by the mid-1960s, judicial courts were rolling back higher education's in loco parentis supervisory role. The 1961 Dixon v. Alabama federal court decision restricted the right of higher education to discipline students for activities conducted off campus and it triggered other challenges to parietal, residential, and disciplinary regulations. A series of court cases in the early 1970s prohibited universities from requiring on-campus residency as a way to offset dormitory construction costs. ${ }^{43}$

Universities responded to these court decisions and the 1971 passage of the Twenty-Sixth Amendment lowering the age of majority from twenty-one to eighteen by ending on-campus parietals and lifting age restrictions for living off campus. ${ }^{44}$ These changes furthered the flight of students off campus: between 1960 and 1980, the number of students living in dormitories declined from 41.5 to 32.8 percent, and many in student affairs worried that residence halls would become a thing of the past. ${ }^{45}$ As one dean recalled about this period, "It was a rare student indeed who wished to live on campus at any university or college in this country." 46

Students played a decisive role in these changes by asserting their constitutional rights of privacy and freedom of association. An outbreak of "panty raids" at universities across the nation in the 1950s and 1960s signaled modern heterosexual students' demands for sexual freedom as well as rejection of the traditional middle-class mores reflected in university social regulations. ${ }^{47}$ "Every day a new policy is levied that encroaches on our freedom," claimed one Ohio University student in the late 1960s, railing against a "paternalistic" policy that required them to live in approved housing until age twenty-three. ${ }^{48}$ At the University of Florida in 1968, women students objected to the extra curfew rules placed on them, claiming that the university administration was "denying the maturity and ability of the women students to effectively administer their own affairs.. . Self-government is not a 'privilege'; it is a right." ${ }^{\prime 49}$ Across the

\footnotetext{
${ }^{42}$ Dongbin Kim and John L. Rury, "The Rise of the Commuter Student: Changing Patterns of College Attendance for Students Living at Home in the United States, 1960-1980," Teachers College Record 113, no. 5 (May 2011), 1031-66.

${ }^{43}$ Philip Lee, "The Curious Life of In Loco Parentis at American Universities," Higher Education in Review 8 (2011), 65-90; and William A. Kaplan and Barbara A. Lee, The Law of Higher Education (San Francisco: Jossey-Bass, 2007), 448, 477; Dixon v. Alabama State Board of Education, 186 F. Supp 945 (M.D. Ala. 1960).

${ }^{44}$ David J. Hanson, The Lowered Age of Majority on Higher Education (Washington, DC: Association of Colleges, 1975), 1; and James R. Cunningham, "Age of Majority and a Private College" (PhD diss., Loyola University Chicago, 1976).

${ }^{45} \mathrm{Kim}$ and Rury, "Changing Profile of College Access," 315.

${ }^{46}$ Robert Etheridge to Mrs. Leslie Taylor, April 1, 1981, Off-Campus Housing, 1974-75 folder, box 5, group 315A, Robert Etheridge Office Files 1974-75, Miami University Archives, Oxford, Ohio.

${ }^{47}$ Rebecca A. André, "Beyond Bride Rules and Panty Raids: Discourses of Femininity, Heterosexuality, and Feminism in OSU Student Residence Policies for Women, 1960-1975" (PhD diss., The Ohio State University, 2001); and Beth Bailey, Sex in the Heartland (Cambridge, MA: Harvard University Press, 2009), chap. 3, 75-104.

${ }^{48}$ Hollow, Ohio University, 192

${ }^{49}$ Hume Hall Honor Council, May 12, 1968, box 5, subseries 49e, Vice President for Student Affairs, Associate Dean of Student Services-Phyllis Meek, Administrative Records, 1956-1987, George A. Smathers Library, University of Florida, Gainesville.
} 
nation, most gender-based campus residency requirements were abolished by the early 1970 s. $^{50}$ Students levied similar rights-based arguments in their claims to be free from university regulations when off campus. Through the 1970s at Miami University in Ohio, students filed four lawsuits against the university's sixty-year-old "no-car" rule," arguing that the university's authority did not extend beyond the campus and that, in setting such regulations, the university was depriving students of their due process and treating them "essentially as nonadults," about which students were "offended and insulted." 51

Students' objections to university housing regulations led, ironically, to higher education's withdrawal from its limited role in discouraging discriminatory rental practices. Since the 1950s, some universities had included nondiscrimination policies in their off-campus approval process, stating that the landlords of university-approved housing must agree not to discriminate on the basis of race, religion, or national origin. This practice had furthered university compliance with emerging federal prohibitions on racial segregation, thus permitting institutions' applications for federal grants. Yet university adherence to these policies was notoriously inconsistent: in 1959, only seventeen of forty-three northern public universities held nondiscriminatory regulations in their approval process, and those that did often did not enforce them. For example, of 447 landlords approved by The Ohio State University in 1959, only fifty-seven, or 13 percent, indicated their willingness to accommodate students without regard to race or color. ${ }^{52}$ At Kent State University in Ohio in 1961, the antidiscrimination requirement the university adopted that year applied to only 15 percent of over 2,000 off-campus housing units available to Kent students. ${ }^{53}$ At the University of Illinois the following year, 51 percent of approved rooming houses continued to violate a university antidiscrimination policy. ${ }^{54}$ When challenged on their meager efforts to enforce antidiscriminatory housing policies, university administrators argued that compliance would interfere with landlord's property rights. ${ }^{55}$

Student civil rights activists publicized this breach of university and city commitment to civil rights by holding public protests and leading rental applicant exercises

\footnotetext{
${ }^{50}$ Gary S. Sprayberry, "Student Radicalism and the Antiwar Movement at the University of Alabama," in Rebellion in Black and White: Southern Student Activism in the 1960s, ed. Robert Cohen and David J. Snyder (Baltimore: Johns Hopkins University Press, 2013), 148-70; Kelly Morrow, "Sexual Liberation at the University of North Carolina," in Cohen and Snyder, Rebellion in Black and White, 193-217; and Joan Page, "UNC Doors Open Wide to Freshmen Coeds," Chapel Hill (NC) Weekly, Nov. 1, 1964, 36.

${ }^{51}$ Curtis W. Ellison, Miami University, 1809-2009: Bicentennial Perspectives (Athens: Ohio University Press, 2009), 335.

${ }^{52}$ William W. Van Alstyne, "Discrimination in State University Housing Programs-Policy and Constitutional Consideration," Stanford Law Review 13, no. 1 (Dec. 1960), 60.

${ }^{53}$ Dan Warner, "No Fanfare for KSU's Ban on Housing Bias," Akron (OH) Beacon Journal, May 25, 1961, 30.

${ }^{54}$ Joy Ann Williamson, Black Power on Campus: The University of Illinois, 1965-75 (Urbana: University of Illinois Press, 2003), 21.

${ }^{55}$ Milton L. McGhee and Ann Fagan Ginger, "The House I Live In: A Study of Housing for Minorities," Cornell Law Quarterly 46, no. 2 (Winter 1961), 194-257; Greer C. Stanford-Randle, "The Black Student Movement at The Ohio State University: Black, Scarlet, and Gray" (master's thesis, Georgia State University, 2010), 7; and John L. Rury and Kim Cary Warren, Transforming the University of Kansas: A History, 1965-2015 (Lawrence: University Press of Kansas, 2015).
} 
that showed that Black students were regularly rebuffed in their efforts to rent an apartment. $^{56}$ Bolstered by two Supreme Court cases in 1950-McLaurin v. Oklahoma State Regents and Sweatt v. Painter-which expanded the scope of educational accessibility to differential treatment outside of the classroom, student activists pressed the argument that sheer admission to a university classroom was not enough and that differences in experiential and physical facilities must be considered as part of "substantive equality."

Facing legal and political fire, and reluctant to enforce regulations on local landlords who housed most of their students, many universities simply closed the offcampus offices that had been responsible for enforcing the antidiscrimination codes and replaced them with voluntary committees staffed by faculty, students, and community members. The purpose of such committees was educational: to explain the university position on racial discrimination and to hear complaints and initiate efforts to discourage discrimination. ${ }^{58}$ As the University of Iowa President argued in 1963 upon the creation of a "Human Right Committee" to do such work, the University's position must be to "inform, persuade, and ultimately convince with the facts." ${ }^{\prime 59}$ The strategy of education over prohibition effectively changed the town-gown relationship over housing from one of regulation to one of voluntary persuasion. In effect, the university had legally and functionally detached itself from the business of off-campus housing, claiming that off-campus housing was not the university's business. In so doing, they took away whatever leverage existed for enforcing university antidiscrimination policies in the community. At the University of Florida, where the off-campus office was being slowly dismantled and the inspection system ended, Opp was furious, arguing that eliminating the inspection process would "eventually emasculate the authenticity of the referral and advisement system" and turn Off-Campus Housing Office into merely a "conveyor belt for referral of marginal or sub-standard units." ${ }^{60}$

As baby boom enrollments slowed in the mid-1970s, higher education administration faced a perfect storm of low enrollments, competing off-campus housing,

\footnotetext{
${ }^{56}$ William J. Shkurti, The Ohio State University in the Sixties: The Unraveling of the Old Order (Columbus: The Ohio State University Press, 2016), 88-89, 164-65; LaDale Winling, "Students and the Second Ghetto: Federal Legislation, Urban Politics, and Campus Planning at the University of Chicago," Journal of Planning History 10, no. 1 (Jan. 2010), 59-86; William Shofner, "NAACP Probing Bias in Housing," Lantern (Columbus, OH), Nov. 24, 1965, 1; "EKU Negroes Submit Discrimination Petition," Kentucky Kernel (University of Kentucky), March 7, 1968, 5; Jeffrey A. Turner, Sitting In and Speaking Out: Student Movements in the American South, 1960-1970 (Athens: University of Georgia Press, 2010), 94, 210-11; John Ehle, The Free Men (New York: Harper \& Row, 1965), 323.

${ }^{57}$ McLaurin v. Oklahoma State Regents, 339 U.S. 637 (1950); Sweatt v. Painter, 339 U.S. 629 (1950); Gary M. Lavergne, Before Brown: Heman Marion Sweatt, Thurgood Marshall, and the Long Road to Justice (Austin: University of Texas Press, 2010).

58“"Committee Announces New Policies on Off-Campus Housing Discrimination," Daily Iowan (University of Iowa), May 28, 1963,1; D. Parker Young, "Student Rights and Discipline in Higher Education," Peabody Journal of Education 52, no. 1 (Oct. 1974), 58-64; and John P. Holloway and Richard A. Tharp, "Recent Developments in Student Affairs," Journal of College \& University Law 2, no. 2 (Winter 1974/1975), 115-22.

59“Committee Announces New Policies on Off-Campus Housing Discrimination," Daily Iowan May 28, 1963, 1.

${ }^{60}$ Carl Opp to Arthur Sandeen, vice president for student affairs, May 30, 1978, Opp Papers.
} 
increasing institutional competition, and reduced state and federal funding. As students seized the freedom to move off campus, they left newly built dormitories empty, undercutting universities' ability to pay off construction debts from the earlier building boom. At Ohio University between 1972 and 1974, total enrollment dropped by 35 percent, caused in part by the opening of other state universities, a gas crisis that made a university in a far corner of the state less accessible, and a decline in state funding and rise in tuition. In 1975, only 60 percent of Ohio University's residence halls were filled, and the university debt on those halls was so large that it appealed to the state for special relief. Eventually, the university sold ten residence halls to the state for conversion to classrooms and research laboratories. ${ }^{61}$ Even when enrollment rebounded later in the decade, on-campus capacity did not, due to high construction costs in a period of double-digit inflation and the now readily available, and increasingly popular, off-campus housing. Few institutions built dormitories during the 1970s, providing the opening for an independent rental market: at the University of Georgia, for example, no dormitories were built between 1970 and 1988 , even as enrollment grew from 16,000 to $26,000 .^{62}$

Facing new student trends and economic strains, many university administrators continued to back away from their institution's involvement in off-campus housing. And most student affairs administrators, drawing on their profession's emerging social psychology emphasis, turned inward to focus on students' experience of residential life in dormitories, largely overlooking the experiences of the majority of students who lived off campus. ${ }^{63}$ For example, in his influential 1974 study, Commuting Versus Resident Students, Arthur Chickering essentially dismissed off-campus students as being less engaged in academic activities and more likely to fail academic courses than those who lived in residence halls. ${ }^{64}$

\section{Trouble in Town}

In college towns in the 1970s, the increased student presence in off-campus housing and decreased university engagement led to significant changes in town geography and culture. ${ }^{65}$ The most notable change was the declining popularity of room rentals

\footnotetext{
${ }^{61}$ Robert E. Mahn and Harry B. Crewson, The Interim Presidency of Harry B. Crewson: September 1, 1974 to August 31, 1975 (Athens: Ohio University Libraries, 2006), 48; and Florence Clark Riffe, A Philosophy of Community: Ohio University in the Ping Years, 1975-1994 (Athens: Ohio University Special Publications, 2003), 42-44.

${ }^{62}$ F. N. Boney, A Walking Tour of the University of Georgia (Athens: University of Georgia Press, 1989), 5.

${ }^{63}$ Hevel, "Toward a History of Student Affairs," 854; John E. Shay Jr., "Private Halls Are Not the Answer," Journal of Higher Education 39, no. 2 (Feb. 1968), 98-101; Alexander Astin, Preventing Students from Dropping Out (San Francisco: Jossey-Bass, 1975); and Alexander Astin, Four Critical Years (San Francisco: Jossey-Bass, 1977).

${ }^{64}$ Arthur W. Chickering, Commuting Versus Resident Students: Overcoming the Educational Inequities of Living Off Campus (San Francisco: Jossey-Bass, 1974). For recent challenges to this argument, see Denise Balfour Simpson and Dana Burnett, "Commuters Versus Residents: The Effects of Living Arrangement and Student Engagement on Academic Performance," Journal of College Student Retention: Research, Theory \& Practice 21, no. 3 (Nov. 2019), 286-304.

${ }^{65}$ Scholars have coined the term studentification to refer to the process by which specific neighborhoods become dominated by student residential occupation. Darren Smith, "The Politics of Studentification and
} 
in family homes, rooming houses, and boarding houses and the increasing popularity of separate apartments. These offered students more personal independence, particularly with the development of local college town restaurants and grocery stores that marketed to students. At Cornell University between 1950 and 1962, the number of students living in rooming houses declined from 23 to 8 percent, while those living in apartments increased from 7 to 29 percent. $^{66}$ At the University of Florida between 1961 and 1966, the number of students who lived in apartments more than doubled. ${ }^{67}$

The increase in college enrollment, with the accompanying increase in off-campus housing, led to a literal dwarfing of the permanent population and realigning of the housing stock from owner-occupied houses to rental units. At the University of Delaware, where no new dormitories were built between 1972 and 1991, the number of rental homes in the college town of Newark, Delaware, increased from 153 in 1983 to 732 in $1990 .{ }^{68}$ Between 1950 and 2000, home ownership rates in the Columbus, Ohio, area near The Ohio State University declined from 50 to 11 percent. $^{69}$ In 1950 in Oxford, Ohio, the home of Miami University, the full-time resident population was 7,000, while full-time university student enrollment was 5,000. About half of those students-about 2,000-lived off campus. By 1970, full-time student enrollment at the university had more than doubled, to 11,000 , and the number of students living off campus also more than doubled, to 5,600, while the town population had remained relatively stable at 7,000. As the number of independent student apartment housing projects increased, older residents who twenty years earlier might have rented a room to a student moved out of town, furthering high-density student residency. With the passage of the Twenty-Sixth Amendment in 1971, those students became a powerful voting block that helped to pass local referenda that expanded liquor sales, leading to concentrated alcohol-related activities at the student residences that now dominated town. After the Miami University no-car ban was lifted in 1997, an increased number of cars in town led the city to construct a city parking garage and parking lot as well as to increase legislative action and policing around parking. ${ }^{70}$ Between 1996 and 2004, the city council conducted six parking studies,

\footnotetext{
'(Un)balanced' Urban Populations: Lessons for Gentrification and Sustainable Communities?," Urban Studies 45, no. 12 (Nov. 2008), 2541-64; Jennifer Massey, Sean Field, and Yolande Chan, "Partnering for Economic Development: How Town-Gown Relations Impact Local Economic Development in Small and Medium Cities," Canadian Journal of Higher Education 44, no. 2 (Aug. 2014), 152-69; John Allinson, "Over-Educated, Over-Exuberant and Over Here? The Impact of Students on Cities," Planning, Practice \& Research 21, no. 1 (Feb. 2006), 79-94; Phil Hubbard, "Regulating the Social Impacts of Studentification: A Loughborough Case Study," Environment and Planning 40, no. 2 (Feb. 2008), 323-41; and D. P. Smith, "Studentification: The Gentrification Factory," in Gentrification in a Global Context: The New Urban Colonialism, ed. Rowland Atkinson and Gary Bridge (London: Routledge, 2005), 72-89.

${ }^{66}$ John Harp and Philip Taietz, "The Cornell Student, 1950 and 1962: A Comparative Report," Cornell Student Life Studies, Report No. 2 (Cornell, NY: Cornell University Agricultural Experiment Station, 1964).

67“Off-Campus Housing Capacities," Oct. 20, 1966, Opp Papers.

${ }^{68}$ Gumprecht, American College Town, 314-17.

${ }^{69}$ Evans-Cowley, "The Effect of Neighborhood-Based Code Enforcement," 112.

70“"Historical Timeline," 1997, Miami University, https://miamioh.edu/about-miami/history-traditions/ timeline/corporate-u/index.html.
} 
created a parking task force, and developed a residential permit parking system. In 2000, the city increased parking staff from two to three full-time officers.

On the other side of the state in this time period, private Oberlin College and the city of Oberlin experienced similar growing pains. Oberlin College enrollment had increased by 25 percent in the 1970s. Typical of other institutions in this period, the college built no new dormitories, while it relaxed its off-campus restrictions, and the number of students living off campus increased by 60 percent. The city population had also grown-from 8,700 to about 10,000 , but at a slower rate than students living off campus, so that between 1972 and 2001 the student percent of the city population rose from 5 percent to over 11 percent. In 2001, the city housing stock was 50 percent rentals, a large majority of which were student rentals. ${ }^{71}$

In spring 1998, Oberlin College president Nancy Dye, noting three serious fires in student rental houses over the previous five months, announced a college housing approval process that prohibited students from living in any off-campus house that failed to meet the city's health and safety licensing standards-a policy much like the one the college, and other colleges, had held fifty years earlier. She also publicized the names and addresses of those properties that did not meet city standards. ${ }^{72}$ The landlords of those properties promptly sued Dye, claiming defamation of character and interference with contracts, and the proposed approval process was halted. ${ }^{73}$

Taking another tactic to address the same problem, in 2003, Dye proposed constructing a college-owned student housing complex, a strategy another private Ohio institution, the University of Dayton, had recently adopted. After the mid-1970s, the local neighborhood adjoining the University of Dayton campus had grown to half student rentals with a notorious party culture that was stigmatizing the university's reputation locally and nationally. ${ }^{74}$ In response, the University of Dayton proceeded to buy over 90 percent of local houses, a process supported by its extra financial reserves and the approval of its eminent domain right to do so "in the public interest," relying on the university's argument that university-owned student housing would improve "behavioral standards."75

In Oberlin, Dye also considered the college's negative public image in promoting a college-owned housing complex, noting that city residents had regularly complained about the negative impact of increased student rental housing in the city, including a decline in single-family and low-income family housing. But in what Dye herself called a "rapid and stunning deterioration of the relationship between the city and

\footnotetext{
${ }^{71}$ Richard K. Dahl, dean of students, to President Robert Fuller, Jan. 5, 1973, box 7, subgroup I, series 11, Oberlin College Archives, Oberlin, Ohio.

72“"Memo to Community, March 11, 1998," Box 7, Series 14, Nancy Dye papers, Oberlin College Archives, Oberlin, Ohio (hereafter cited as Nancy Dye Papers).

${ }^{73}$ The landlords dropped this suit, but they continued their suit against the city, which was settled in 2006. "Long-Standing Rooming House Feud Ends," Oberlin (OH) News-Tribune, June 13, 2006, 1.

${ }^{74}$ Scott Kinnison, "Non-Student Residents Describe Life in 'Ghetto," Flyer News (University of Dayton, $\mathrm{OH})$, Oct. 7, 1985, 3; and "Unique Place: Ghetto Residents Enjoy Where They Live; Say Most Students Are Good Neighbors," Flyer News (University of Dayton, OH), Oct. 12, 1979, 12.

${ }^{75}$ Sandy Theis, "Regents Back UD Plan to Use Eminent Domain to Get Property," Dayton (OH) Daily News, July 15 1989, 1; Don Liebrect, “Ghetto Rehab Progresses with Ross Buy-Out," Flyer News (University of Dayton, OH), Nov. 6, 1989, 2; and "University Bumps Ross Out with Eminent Domain," Flyer News (University of Dayton, OH), Sept. 11, 1989, 1.
} 
the college," the city council objected to the college plan because it would introduce more tax-exempt property to the city and because the loss of students in extant offcampus housing would economically harm the already fiscally impoverished city. ${ }^{76}$

Dye's reflection on the rupture in town-gown relations exemplifies the changed dynamics in all college towns in the late twentieth century. She surmised that the tensions resulted in part from her own neglect of town-gown relations due to her extensive traveling, recent conflicts with the city police and a county prosecutor who seemed obsessed with hounding students over drugs, and the city's financial crisis that coincided with the college reaching its $\$ 165$ million capital campaign goal. Furthermore, she recognized that in the thirty years since the college had increased enrollments and sent students into town, landlords had come to rely on student rentals, and the city, which appeared to be bullied by a powerful lobbying group of landlords, had neglected to keep up its housing codes. Granted, the city seemed to constantly forget the good that the college did for it, including donations to city services and subsidizing the hospital, public school partnerships, and free tuition for local high school graduates. ${ }^{77}$ In a letter to her staff, Dye stated:

Then too it is always the case, even in good times, that Oberlin, like every small town with a college in it, feels put upon. My sense is that Oberlin, in some collective psychological way, feels deeply dependent upon the good will of the College. Although this is never a sentiment that is verbalized, I think that everyone who lives in Oberlin recognizes that without the College, the town would be like all the other little southern Lorain County towns. These feelings of dependency, whether consciously realized or not, render the community easily angered by any College action that can be seen to ignore or hurt the town. ${ }^{78}$

What Dye identified as the increasing tension between town and gown over offcampus students was already visible in urban planning strategies in which city leaders tried to legislatively restrain off-campus student housing. The 1974 Supreme Court decision Village of Belle Terre v. Boraas initially seemed to offer college towns some support in controlling student housing growth. The case involved a group of college students at the State University of New York at Stony Brook who rented a house zoned for single-family residence in the Village of Belle Terre, which restricted one-family dwellings to "one or more persons related by blood, adoption, or marriage, living and cooking together as a single housekeeping unit," or two people unrelated by blood or marriage. ${ }^{79}$ The village charged that a group of students did not constitute a family and brought an order of eviction on the rental unit. In response, the landlord sued the village and lost when the Supreme Court held that local

\footnotetext{
${ }^{76}$ Email from Nancy Dye to Mike Frantz, Nov. 17, 2003, Nancy Dye Papers.

${ }^{77}$ Many college towns have a tradition of PILOTS-Payment in Lieu of Taxes-under which the university voluntarily pays for a specific public service, in acknowledgement that the tax-exempt status of an educational institution undercuts the local city budget. The practice is welcome, but it is not required. Mary Lynne Corn, "PILT (Payments in Lieu of Taxes): Somewhat Simplified" (Washington, DC: Congressional Research Service, Library of Congress, 1998).

${ }^{78}$ Email from Nancy Dye to staff [Tom, Peter, Barbara and Harry], Dec. 28, 2003, Nancy Dye Papers.

${ }^{79}$ Village of Belle Terre v. Boraas, 416 U.S. 1 (1974)
} 
governments had the right to establish residential zones that limited the number of unrelated individuals that may inhabit a dwelling. ${ }^{80}$ Within a few years, many college towns had passed such ordinances, but in effect, the ordinances merely prohibited the use of housing that students were no longer interested in anyway-large boarding houses or rooming houses with multiple residents. Student housing developments began to comply with zoning laws that limited the number of unrelated occupants, thus furthering the development of small student-housing apartments.

Other college town strategies for restricting student housing included expanding nuisance ordinances and inspection protocols as well as identifying a particular rental property as a "student home" if the primary occupation of a certain number of residents was student. ${ }^{81}$ In 2000, the local borough of West Chester, Pennsylvania, approved such a restrictive zoning ordinance, claiming that "groups of students, compared to other unrelated cohabiting individuals, have different hours, work and social habits and frequently cause noise and disturbances in a residential neighborhood." The borough went on record opposing the local state university's expansion into the community in order "to preserve the residential character of the neighborhoods in the Borough and to protect the health, safety, welfare and the quality of life of the Borough's residents by avoiding an institutional atmosphere caused by oversaturation of areas with student homes." ${ }^{\prime 2}$ But cities found that the university was not the only challenger in their efforts to control student housing: landlords also took to the courts. In the 2015 Ohio case of Baker v. City of Portsmouth, a federal district court limited the right of cities to inspect rental properties, arguing that the city's rental dwelling code violated landlord's constitutional protections to due process and against unreasonable searches. ${ }^{83}$

Today, many college towns are marked by the newest iteration of off-campus student housing: large multiunit development complexes designed specifically for, or "purpose built," for students. These include such amenities as fully furnished units, study areas, pools, exercise rooms, movie theaters, clubhouses, and roommate matching. ${ }^{84}$ Proposed as apartment complexes in appropriately zoned regions, cities are limited in their ability to reject such projects because conventional by-right zoning codes cannot be used to predict a possible impact. Cities' inability to make discretionary judgments allows developers to identify purpose-built student apartment

\footnotetext{
${ }^{80}$ Village of Belle Terre v. Boraas, 416 U.S. 1 (1974); Jack S. Frierson, "How Are Local Governments Responding to Student Rental Problems in University Towns in the United States, Canada, and England," Georgia Journal of International and Comparative Law 33, no. 2 (2005), 497.

${ }^{81}$ Duncan Associates, "Analysis of Issues Regarding Student Housing Near the University of Florida," (Chicago: Duncan Associates, 2002), Appendix B.

${ }^{82}$ Borough of West Chester, Pennsylvania, Resolution No. 18-2000, Oct. 18, 2000.

${ }^{83}$ Baker v. City of Portsmouth, Case No. 1:14cv512 (S.D. Ohio Sep. 30, 2015); Conor Morris, "Ruling in Rental Inspection Case Could Affect Athens, Nelsonville" Athens (OH) News, Oct. 7, 2015; and Bob Ratterman, "Oxford Updating Rules for Rental Property Inspections," Dayton (OH) Daily News, Oct. 6, 2016, https://www.daytondailynews.com/news/oxford-updating-rules-for-rental-property-inspections/8hMIQfTyKbEdpjVGDYmmrK/.

${ }^{84}$ Deidre Fernandes, "Pricey Campus Housing Triggers a Debate," Boston Globe, Jan. 5, 2019; and Daniel J. McGraw, "The College That Ate a City" Next City, April 18, 2016, https://nextcity.org/features/view/sanmarcos-fastest-growing-city-texas-state-university-affordable-housing.
} 
complexes as "single-family" units. ${ }^{85}$ In reality, because many purpose-built housing complexes rent by the room, they effectively prohibit families, for whom multiple room rentals would be prohibitively expensive. In addition, some institutions of higher education partner with for-profit student housing companies in public-private partnerships (PPPs) that allow for expanded student housing in coordination with private investment. ${ }^{86}$

Purpose-built student apartment complexes have further changed both the geography of college towns and the culture of off-campus living in a number of ways. Such units serve essentially as private auxiliaries to university housing, offering many conveniences and a level of supervision that is not formally connected to the university. When students are attracted to the new features, old housing stock is left empty, leaving literally thousands of empty beds across the community.

\section{Conclusion}

Today, as has historically been the case, over half of all college students live independently off campus. ${ }^{87}$ In many college towns, such housing is congregated in one or two residential areas near campus so that virtually all residents are student peers, living, partying, and enjoying time in a community of their own making. At many colleges, students live off campus their entire four years; at others, residency requirements keep students on campus for one or two years and then they are all but required to live off campus due to a shortage of on-campus housing. In these cases, juniors and seniors, who have spent two years under the watchful eye of trained student affairs professionals in the residence halls, are sent out to live on their own, sign their own leases, do their own housekeeping, uphold the law, and learn how to live with neighbors. While many institutions host off-campus-housing staff or websites that provide students with information and advice, institutions maintain clear disclaimers about the limits of their administrative responsibility and legal liability. Some universities literally, and legally, wash their hands of students once they step off campus.

Higher education research, too, tends to avoid the subject of off-campus housing. Studies of student retention rates tend to center on students' income, racial and gender identity, resources, and academic preparation, with only occasional reference to housing issues, except to refer to "commuting students," a definition that does not necessarily capture the experience of full-time students who live in the neighboring

\footnotetext{
${ }^{85}$ Robert H. Nelson, “A Private Property Right Theory of Zoning,” Urban Lawyer 11, no. 4 (Fall 1979), 713-32; and Lisa Dvorak and Kate Rousmaniere, "1,000 Cuts: The Rise of Purpose-Built Student Housing and Installment Leases," paper presented at the Annual Meeting of the International Town \& Gown Association, (Virtual) Boulder, CO, June 2020.

${ }^{86}$ Kevin R. McClure, Andrew J. Ryder, and James M. DeVita, "Public-Private Partnerships in College Student Housing: Lessons from Three Institutions," Journal of College and University Student Housing 43, no. 2 (2017), 72-93.

${ }^{87}$ Of undergraduate students attending US postsecondary institutions (two- and four-year colleges and universities) in the 2007-2008 academic year, 54 percent lived off campus, 14 percent lived on campus, and 32 percent lived with parents or relatives. T. D. Snyder and S. A. Dillow, Digest of Education Statistics 2011 (Washington, DC: US Department of Education, 2012), 342.
} 
college town. ${ }^{88}$ Studies of college students' alcohol use rarely refer to the impact of residence, although, unsupervised, students in off-campus housing neighborhoods are highly susceptible to peer pressure, including extreme binge drinking that often leads to sexual and interpersonal violence. ${ }^{89}$ The Association of College and University Housing Officers-International, the leading professional organization for campus housing and residence life professionals, also centers on campus residency topics, inadvertently echoing its own 1959 claim that off-campus housing was "the neglected stepchild of university life." 90 An emerging field of town-gown scholars and practitioners provides some analysis of off-campus housing in the context of university-community relations, albeit this work remains somewhat marginalized from general higher education literature. ${ }^{91}$

Yet what happened to college towns over the last century is critical to understanding many of the economic, legal, and political dynamics of modern higher education. Structural dynamics, from federal law and governmental funding to local zoning codes, have impacted not only the academic institution but the local communities in which they are located.

This essay is an argument for considering the spatial, economic, and social context of higher education in its local community. Although popular images of higher education center on campus dormitory life, more than half of all American college students have always lived off campus in the local or neighboring town. The history of the impact of these residential patterns on the local community has been largely overlooked, as colleges and universities tend to be seen in a way that they themselves promote: as independent, self-defined, and unique institutions. In fact, college towns and "town-gown" relationships have played a significant part in shaping the identity of

\footnotetext{
${ }^{88}$ Halley Alfano and Nina Eduljee, "Differences in Work, Levels of Involvement, and Academic Performance between Residential and Commuter Students," College Student Journal 47, no. 2 (Jan. 2013), 334-42.

${ }^{89}$ According to the National Institutes of Health, almost 2,000 college students between the ages of eighteen and twenty-four die yearly from unintentional, alcohol-related injuries, including motor vehicle crashes. While the national data does not identify residence, a simple search of news sources reveals that a large number of student tragedies happen at off-campus parties. Ralph W. Hingson, Wenxing Zha, and Elissa R. Weitzman, "Magnitude of and Trends in Alcohol-Related Mortality and Morbidity among US College Students Ages 18-24, 1998-2005," Journal of Studies on Alcohol and Drugs, Supplement 16 (July 2009), 12-20; and Carlos Blanco, et al., "Mental Health of College Students and Their Non-College-Attending Peers: Results from the National Epidemiologic Study on Alcohol and Related Conditions," Archives of General Psychiatry 65, no. 12 (Dec. 2008), 1429-37.

${ }^{90}$ For both student affairs research on housing and much of the discussion about expensive amenities in housing centers in residence halls on campus, see Robert A. Bonfiglio, "What the Building Boom Says about Campus Values," About Campus 9, no. 5 (Nov./Dec. 2004), 27-29; Brian Jacob, Brian McCall, and Kevin Stange, "College as Country Club: Do Colleges Cater to Students' Preferences for Consumption?," Journal of Labor Economics 36, no. 2 (April 2018), 309-48; and Courtney Rubin, "Making a Splash on Campus: College Recreation Now Includes Pool Parties and River Rides," New York Times, Sept. 19, 2014.

${ }^{91}$ Michael Fox, Town and Gown: From Conflict to Cooperation (Union, ON: Municipal World, 2014); Stephen M. Gavazzi and Michael Fox, "A Tale of Three Cities: Piloting a Measure of Effort and Comfort Levels Within Town-Gown Relationships," Innovative Higher Education 40, no. 3 (June 2015), 189-99; and Stephen M. Gavazzi, Michael Fox, and Jeff Martin, "Understanding Campus and Community Relationships Through Marriage and Family Metaphors: A Town-Gown Typology," Innovative Higher Education 39, no. 5 (Nov. 2014), 361-74.
} 
each body, for better or worse, and both intentionally and accidentally. The crux of the town-gown relationship is, and has always been, around the joint use of physical space, primarily off-campus student housing. Higher education is more than the classroom, and more than the campus.

Kate Rousmaniere is Professor in the Department of Educational Leadership, Miami University, Oxford, Ohio, and former mayor of the City of Oxford, Ohio. Thanks to Tim Cain, Mahauganee Shaw Bonds, Amanda Ingram, Sevan Terzian, and many members of the International and Ohio Town Gown Associations for their support of this research.

Cite this article: Kate Rousmaniere, "What Happened to Your College Town: The Changing Relationship of Higher Education and College Towns, 1940-2000," History of Education Quarterly 61, no. 3 (August 2021), 320-340. https://doi.org/10.1017/heq.2021.31. 